\title{
DISTRIBUTION OF SANDFLIES (DIPTERA: PHLEBOTOMINAE) IN FOREST REMNANTS AND ADJACENT MATRIX HABITATS IN BRAZILIAN AMAZONIA
}

\author{
DE LUCA, A. S., ${ }^{1}$ VASCONCELOS, H. L. ${ }^{2}$ and BARRETT, T. V. ${ }^{3}$ \\ ${ }^{1}$ Departamento de Biologia, Universidade Estadual de Mato Grosso (UNEMAT), \\ C.P. 324, CEP 78580-000, Alta Floresta, MT, Brazil \\ ${ }^{2}$ Instituto de Biologia/Universidade Federal de Uberlândia, C.P. 593, CEP 38400-902, Uberlândia, MG, Brazil \\ ${ }^{3}$ Coordenação de Pesquisas em Ciências da Saúde, Instituto Nacional de Pesquisas da Amazônia (INPA), \\ C.P. 478, CEP 69011-970, Manaus, AM, Brazil \\ Correspondence to: Heraldo L. Vasconcelos, Instituto de Biologia/Universidade Federal de Uberlândia, C.P. 593 , \\ CEP 38400-902, Uberlândia, MG, Brazil, e-mail: heraldo@umuarama.ufu.br \\ Received September 17, 2001 - Accepted April 29, 2002 - Distributed August 31, 2003
}

(With 2 figures)

\begin{abstract}
We studied the distribution of sandflies (Diptera: Phlebotominae) - insect vectors of several diseases, including leishmaniasis - at the interface between primary forest and cattle pasture and between primary forest and secondary forest ( $<15$ yr old) in Southern Brazilian Amazonia. Sandflies were collected by using a combination of light traps and traps having vertebrates as baits. Strong differences in abundance and species richness were found between primary forests and pastures. Very few sandfly species were found in the pastures, and those that were found generally occurred at lower densities when compared to the adjacent forest. At least one species (Lutzomyia lainsoni), however, can become extremely abundant in pastures, possibly depending on the presence of cattle and water bodies. Differences between primary forests and secondary forests were not so strong, although the latter usually had fewer species and lower population abundances. No species were exclusively found in pastures or secondary forests; the species present in these two habitats were a subset of those found in primary forests. The distance to the edge did not affect the abundance, richness and composition of sandfly species in primary forests. The abundance and richness of sandflies, however, was greater in forest edges facing pastures than those facing secondary forests. This pattern could not be explained by an influx of species and individuals from the adjacent pasture, suggesting the existence of in situ differences between the different types of forest edges studied.
\end{abstract}

Key words: Amazonia, edge effects, forest fragmentation, Phlebotominae, Lutzomyia.

\section{RESUMO}

\section{Distribuição de flebótomos (Diptera: Phlebotominae) em remanescentes florestais e habitats matrizes adjacentes na Amazônia Brasileira}

Estudamos a distribuição de flebótomos (Diptera: Phlebotminae) - insetos vetores de várias doenças, incluindo-se a leishmaniose - na interface entre a pastagem e a floresta primária e entre a capoeira e a floresta primária, em Alta Floresta, no sul da Amazônia. Os flebótomos foram coletados com armadilhas de luz e com o uso de vertebrados como iscas. Foram detectadas fortes diferenças na abundância e na riqueza de espécies entre florestas primárias e pastagens. Poucas espécies de flebótomos foram encontradas nas pastagens, e nestas em geral as populações eram esparsas. Entretanto, ao menos uma espécie (Lutzomyia lainsoni) pode ser bastante abundante nas pastagens, possivelmente em função da congregação de gado em torno de pequenos corpos d'água. As diferenças entre as capoeiras e a floresta primária foram relativamente pequenas, embora as capoeiras apresentassem menor abundância e menor diversidade de 
espécies de flebótomos. Nenhuma espécie foi registrada exclusivamente nas pastagens ou capoeiras; as espécies presentes nesses ambientes representaram um subconjunto das espécies da floresta. A distância até a borda da floresta não afetou a abundância, a riqueza e a composição de espécies de flebótomos nos fragmentos florestais. A abundância e a riqueza de espécies de flebótomos, entretanto, foram maiores em bordas de floresta adjacentes à pastagem do que naquelas adjacentes à capoeira. Este padrão não pode ser explicado por uma entrada de flebótomos da pastagem adjacente, o que sugere a existência de diferenças intrínsecas entre os dois tipos de borda estudados.

Palavras-chave: Amazônia, efeitos de borda, fragmentação florestal, Phlebotominae, Lutzomyia.

\section{INTRODUCTION}

It is well established that tropical forest fragmentation can substantially alter forest structure and microclimate, changes which, in consequence, directly or indirectly affect the composition of fragment biotas (Saunders et al., 1991; Laurance et al., 1997b). Information about the nature and magnitude of the response of tropical species to these changes is, in many cases, limited or lacking. One group that has been particularly neglected in studies of forest fragmentation is that of insect parasites of vertebrates, in spite of the fact that some of these are important vectors of diseases and can thus affect the population dynamics of vertebrates. A recent review of invertebrate responses to forest fragmentation (Didham, 1997), for instance, does not record a single study on vertebrate parasites.

Sandflies (Diptera: Phlebotominae) are vectors of several diseases, including leishmaniasis (Young \& Duncan, 1994). The larvae usually live in the litter layer, feeding on organic matter. Feeding habits of adults vary with sex. Both sexes feed on plant sugars, whereas females are also hematophagous and attack a wide range of warm- and cold-blooded vertebrates. Forest fragmentation can potentially affect sandflies in several ways, by affecting resource levels for larvae, adults, or both. For instance, the abundance, biomass, and diversity of some vertebrate hosts (e.g. small mammals) can increase after forest fragmentation (Malcolm, 1997a). Similarly, the density of understory vegetation tends to increase near the fragment edges (Malcolm, 1994), and with it, probably, the availability of plant resources to adults. Finally, litter cover is know to be affected by forest fragmentation (Carvalho \& Vasconcelos, 1999; Didham \& Lawton, 1999) and therefore conditions for growing larvae can also be altered in fragments and along forest edges.

Empirical evidence indicates that edge effects are one of the main processes behind changes in forest structure, microclimate, and species population levels in forest fragments (Murcia, 1995). Structural and functional characteristics of the surrounding matrix habitat are also of importance in determining not only the composition of fragment biotas, but also the extent of edge-induced habitat changes (Laurance, 1991; Gascon et al., 1999; Mesquita et al., 1999). Here, we studied the effects of distance to forest edge on the abundance, richness and composition of sandfly species on forest edges surrounded by two contrasting matrix habitats: cattle pastures and secondary forests.

\section{METHODS}

The study was conducted in the municipality of Alta Floresta, Mato Grosso State, in Southern Brazilian Amazonia $\left(10^{\circ} \mathrm{S}, 55^{\circ} \mathrm{W}\right.$; Fig. 1). The original vegetation of Alta Floresta is mostly dense lowland ( 250 to $480 \mathrm{~m}$ a.s.1.) forest. The climate is typically tropical-rainy, with average temperatures of $24^{\circ} \mathrm{C}$, humidity of $85 \%$, and precipitation of approximately 2,500 $\mathrm{mm}$ per year (Secretaria Municipal da Agricultura de Alta Floresta, unpublished data).

We worked in three different farms (hereafter Pelegrini, Ouro Verde and Santa Lucia), separated from each other by distances of over $60 \mathrm{~km}$ (Fig. 1). In each farm we established two sampling sites, one located at the edge between the primary forest and pasture, and the other at the edge between the primary forest and regenerating secondary forest. In each sampling site we established five 200-m long transects, at different distances and parallel to the border between primary forest and the adjacent matrix habitat (pasture or secondary forest). Two of the transects were located in the matrix habitat, one at $30 \mathrm{~m}$ and the other at $150 \mathrm{~m}$ from the forest edge. The other three transects were established inside the forest at 2,30 and $150 \mathrm{~m}$ from the edge. 
Deforestation in Alta Floresta is widespread, so that only fragments of primary forest remain in all farms. At Pelegrini, we worked in a fragment of $120 \mathrm{ha}$. Collections of sandflies were performed in one of the fragment's edges surrounded by pasture and in another edge surrounded by secondary forest. At Santa Lucia, a 80 ha fragment was studied, whereas at Ouro Verde two fragments were studied, one with 30 ha, surrounded by pasture, and one with 60 ha, surrounded by secondary forest. In all cases, we kept a minimum distance of $250 \mathrm{~m}$ between transects located in the different forest edges. All secondary forests studied originated from abandoned coffee, rice or corn plantations and varied in age from 3 to 15 years old, and in canopy height from 4 to $15 \mathrm{~m}$. We collected sandflies using CDC and Disney traps (Sudia \& Chamberlain, 1962; Disney, 1966). In each transect, five CDC traps were set 1 $\mathrm{m}$ above the ground, and were put in operation for three non-consecutive nights (in June, August and November 1999; all around the period of the new moon) from $7 \mathrm{pm}$ to 6 am the following morning.
Disney traps make use of live animals to attract sandflies. In each transect, five traps were set (on days different from those used to collect with CDCs) and remained in operation from $5 \mathrm{pm}$ to $6 \mathrm{am}$. The traps were set on three different occasions (between June and November), using chickens as bait during the first one, and guineapigs in the remaining ones. Collected specimens were prepared for identification by clearing in a sodium hydroxide solution followed by liquid phenol (Young \& Duncan, 1994).

\section{Data analysis}

We used nested analysis of variance, having replicated transects (within habitats and site) as the nested factor, to determine if there were differences in the abundance and species richness of sandflies among habitats. Data on sandfly abundance were transformed $\left(\log _{10}\right)$ prior to the analyses. We also used analysis of variance to evaluate the effect of matrix type and the effect of distance to forest edge on the abundance and richness of sandflies in primary forest.

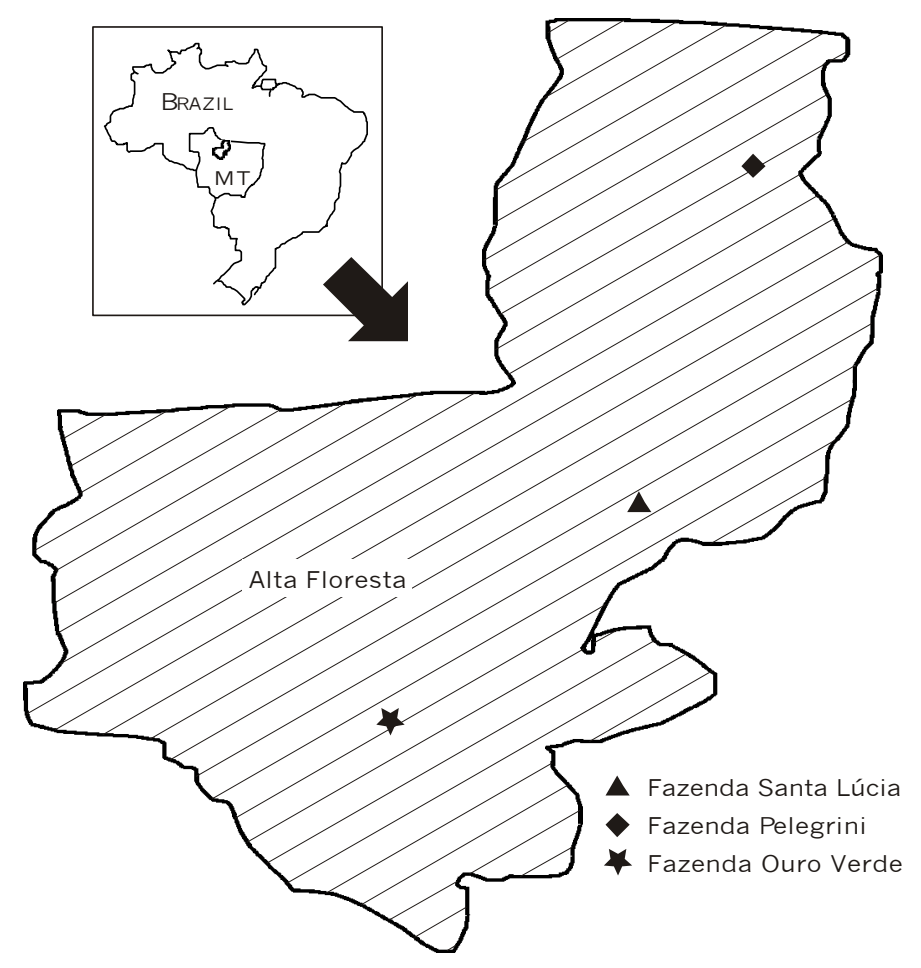

Fig. 1 - Map showing the location of Alta Floresta in Brazil and Mato Grosso State (MT) and the location of the three study sites within Alta Floresta. 
To analyze effects on species composition, data on species abundances per transect (log transformed) were subjected to ordination analysis (Nonmetric Multidimensional Scaling), after creating a dissimilarity matrix using normalized Euclidean distances. The resulting ordination scores (for a two dimensional solution) were used as dependent variables in a multivariate analysis of variance, which analyzed the effects of habitat and distance to forest edge on sandfly species composition.

\section{RESULTS}

\section{Species richness}

In total, 52 sandfly species from the genus Lutzomyia and three from the genus Brumptomya were recorded (Appendix 1). There were strong and significant differences in species richness according to habitat type $(\mathrm{F}=65.9, \mathrm{df}=3,8, \mathrm{p}<0.001$; Table $1)$. The average number of species captured per transect was significantly smaller in the pastures than in primary and secondary forests (post-hoc, Tukey pairwise comparisons test, $\mathrm{p}<0.001$ in all comparisons). Transects in secondary forests contained fewer species than those in primary forest $(p<0.003)$. The number of species in primary forest transects varied according to the type of matrix habitat, and those adjacent to pastures had more species than those adjacent to secondary forests $(p=0.009)$. Distance to forest edge did not affect the number of species captured per transect $(\mathrm{F}=0.30, \mathrm{df}=2,12, \mathrm{p}=0.74$; Table 1) and there was no interaction between the effects of the matrix habitat and the effects of distance to edge $(\mathrm{F}=0.29, \mathrm{df}=2,12, \mathrm{p}=0.74)$.

\section{Abundance}

A total of 3929 sandflies were collected, with a ratio of 2.2 males to 1 female. The abundance of sandflies varied with habitat type $(\mathrm{F}=16.5, \mathrm{df}=$ $2,8, \mathrm{p}<0.001$; Table 1). The average number of individuals collected per transect was smaller in pastures than in primary forests, regardless of matrix type $(\mathrm{p}<0.008)$. Abundance of sandflies in the pastures was also smaller than in secondary forests, but the difference was only close to significance ( $\mathrm{p}=$ 0.052 ). Although sandflies were generally rare in pastures, they were extremely common in one site (Ouro Verde). At this site we collected over 500 sandflies per transect, almost all of which from a single species (L. lainsoni), whereas in the other two sites 10 or fewer flies were captured per transect.
There was no significant effect of distance to forest edge on the abundance of sandflies $(F=0.83$, $\mathrm{df}=2,12, \mathrm{p}=0.46$ ). However, abundance of sandflies in primary forests was affected by matrix type $(\mathrm{F}=$ $7.88, \mathrm{df}=1,12, \mathrm{p}=0.016$ ). We found more sandflies in forests adjacent to pastures than in those adjacent to secondary forests (Table 1). There was no significant interaction between the effects of edge distance and matrix type $(\mathrm{F}=0.31, \mathrm{df}=2,12, \mathrm{p}=$ $0.73)$.

We analyzed the effects of distance to forest edge on the abundance of each of the six most common species in our study sites (Table 1), but for none of them was there a significant effect ( $p$ > 0.5 in all cases). For two of these species, however, a matrix effect was detected. Both L. flaviscutellata $(\mathrm{F}=10.51, \mathrm{df}=1,12, \mathrm{p}=0.007)$ and L. comple$x a(\mathrm{~F}=5.88, \mathrm{df}=1,12, \mathrm{p}=0.032)$ were more common in forests adjacent to pastures than in those adjacent to secondary forests.

\section{Species composition}

Results of the ordination analysis showed that habitats are clearly discriminated according to sandfly species composition (Multivariate Test Statistics, Wilks' Lambda $=0.11, \mathrm{~F}=11.41, \mathrm{df}=$ $6,34, \mathrm{p}<0.001$; Fig. 2). Axis 1 of the ordination analysis shows a gradient from pastures to secondary forests and primary forests. Positioning of transects along axis 1 reflected the fact that most primary forest species were rare or were not found in the pasture areas. Also, although most primary forest species were found in secondary forests, these were usually found at lower densities (Table 1). This explains why most correlations between axis 1 ordination scores and the abundance of individual species were strongly negative (Table 2 ).

Positioning of transects along axis 2 probably reflects an effect of site on species composition. The strongest correlation between axis 2 ordination scores and abundance was for $L$. lainsoni, a species particularly abundant in the pasture and adjacent primary forest at Ouro Verde.

The other species to show a significant correlation with scores from ordiantion axis 2 ( $L$. claustrei, L. shawi, L. ubiquitalis and L. migonei, Table 2) were either more abundant in transects at Ouro Verde (except for those at the pasture, where these species were extremely rare), than those at the other two sites (Pelegrini and Santa Lucia) or more abundant in Pelegrini than in the other sites. 
We found no evidence for an effect of distance to forest edge on species composition, since positioning of the transects on the ordination space had no relationship with distance to forest edge (Multivariate Test Statistics, Wilks' Lambda $=0.87, \mathrm{~F}=$ $0.98, \mathrm{df}=2,13, \mathrm{p}=0.40$ ).

\section{DISCUSSION}

In most sites, very few sandfly species and individuals were found in pastures, indicating that pastures are generally an inhospitable habitat for sandflies. Depending on local conditions, however, at least one species can exploit pasture areas. This was the case for L. lainsoni at Ouro Verde, where this species was extremely abundant, attaining densities over three times greater than those found in primary forest. At this site, cattle congregated around a water-hole near the traps, suggesting that the distribution of L. lainsoni is affected by the distribution of vertebrate hosts. The possibility that L. lainsoni was breeding in the pasture cannot be excluded on the present evidence, but migration of adults from the forest is more likely.

TABLE 1

Species richness (no. species per transect), total abundance (no. individuals per transect - log transformed), and abundance of the six most common sandfly species (log transformed) at varying distances from the edge of primary forest and in the adjacent matrix habitats. Values represent the mean \pm 1 S.D.

\begin{tabular}{|c|c|c|c|c|c|c|}
\hline \multirow[b]{2}{*}{ Variable } & \multirow[b]{2}{*}{ Matrix type } & \multirow[b]{2}{*}{ Matrix } & \multicolumn{4}{|c|}{ Primary forest } \\
\hline & & & $\begin{array}{c}2 \mathrm{~m} \text { from } \\
\text { edge }\end{array}$ & $\begin{array}{c}30 \mathrm{~m} \text { from } \\
\text { edge }\end{array}$ & $\begin{array}{c}150 \mathrm{~m} \text { from } \\
\text { edge }\end{array}$ & All distances \\
\hline \multirow[t]{2}{*}{ No. species } & Pasture & $4.3 \pm 3.8$ & $24.3 \pm 0.6$ & $26.3 \pm 5.8$ & $22.3 \pm 2.5$ & $24.3 \pm 3.6$ \\
\hline & $\begin{array}{l}\text { Secondary } \\
\text { forest }\end{array}$ & $12.8 \pm 4.2$ & $19.0 \pm 2.6$ & $19.6 \pm 5.0$ & $19.6 \pm 7.2$ & $19.4 \pm 4.6$ \\
\hline \multirow[t]{2}{*}{ Total abundance } & Pasture & $1.31 \pm 1.17$ & $2.24 \pm 0.18$ & $2.26 \pm 0.30$ & $2.12 \pm 0.12$ & $2.21 \pm 0.20$ \\
\hline & $\begin{array}{c}\text { Secondary } \\
\text { forest }\end{array}$ & $1.72 \pm 0.17$ & $2.04 \pm 0.25$ & $1.85 \pm 0.20$ & $1.82 \pm 0.28$ & $1.90 \pm 0.24$ \\
\hline \multirow[t]{2}{*}{ L. flaviscutellata } & Pasture & 0 & $1.45 \pm 0.37$ & $1.47 \pm 0.33$ & $1.55 \pm 0.26$ & $1.49 \pm 0.28$ \\
\hline & $\begin{array}{l}\text { Secondary } \\
\text { forest }\end{array}$ & $0.36 \pm 0.32$ & $1.14 \pm 0.38$ & $0.96 \pm 0.31$ & $0.85 \pm 0.33$ & $0.98 \pm 0.32$ \\
\hline \multirow[t]{2}{*}{ L. lainsoni } & Pasture & $0.92 \pm 1.43$ & $1.28 \pm 0.96$ & $1.40 \pm 0.61$ & $0.91 \pm 0.80$ & $1.19 \pm 0.73$ \\
\hline & $\begin{array}{c}\text { Secondary } \\
\text { forest }\end{array}$ & $0.63 \pm 0.61$ & $0.93 \pm 0.40$ & $0.58 \pm 0.57$ & $0.57 \pm 0.23$ & $0.69 \pm 0.41$ \\
\hline \multirow[t]{2}{*}{ L. devisi } & Pasture & $0.18 \pm 0.21$ & $1.26 \pm 0.19$ & $1.48 \pm 0.46$ & $1.01 \pm 0.28$ & $1.25 \pm 0.35$ \\
\hline & $\begin{array}{c}\text { Secondary } \\
\text { forest }\end{array}$ & $0.79 \pm 0.39$ & $1.17 \pm 0.62$ & $0.77 \pm 0.52$ & $1.11 \pm 0.25$ & $1.02 \pm 0.46$ \\
\hline \multirow[t]{2}{*}{ L. whitmani } & Pasture & $0.08 \pm 0.19$ & $0.93 \pm 0.08$ & $0.73 \pm 0.34$ & $0.87 \pm 0.40$ & $0.84 \pm 0.28$ \\
\hline & $\begin{array}{l}\text { Secondary } \\
\text { forest }\end{array}$ & $0.54 \pm 0.60$ & $0.99 \pm 0.66$ & $0.90 \pm 0.53$ & $0.60 \pm 0.60$ & $0.83 \pm 0.55$ \\
\hline \multirow[t]{2}{*}{ L. complexa } & Pasture & $0.08 \pm 0.19$ & $0.66 \pm 0.39$ & $1.07 \pm 0.21$ & $0.59 \pm 0.11$ & $0.77 \pm 0.32$ \\
\hline & $\begin{array}{c}\text { Secondary } \\
\text { forest }\end{array}$ & $0.47 \pm 0.42$ & $0.23 \pm 0.40$ & $0.30 \pm 0.52$ & $0.47 \pm 0.47$ & $0.34 \pm 0.42$ \\
\hline \multirow[t]{2}{*}{ L. claustrei } & Pasture & 0 & $0.47 \pm 0.58$ & $0.54 \pm 0.69$ & $0.62 \pm 0.56$ & $0.54 \pm 0.53$ \\
\hline & $\begin{array}{l}\text { Secondary } \\
\text { forest }\end{array}$ & $0.05 \pm 0.12$ & $0.33 \pm 0.35$ & $0.36 \pm 0.32$ & $0.59 \pm 0.52$ & $0.43 \pm 0.37$ \\
\hline
\end{tabular}




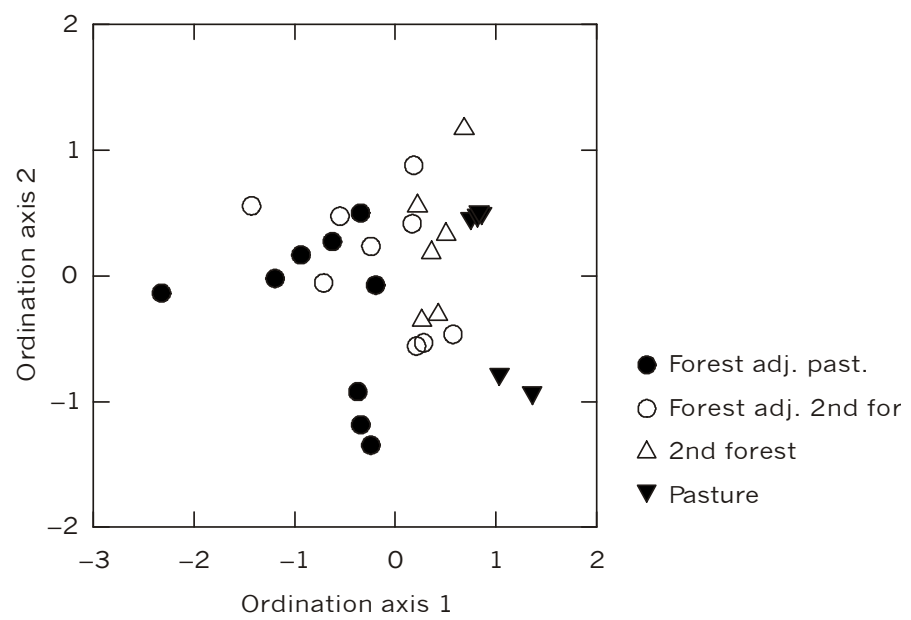

Fig. 2 - Ordination plot of transects established in two types of matrix habitats (pasture and secondary forest), and in patches of primary forest adjacent to pastures or to secondary forests.

TABLE 2

Spearman correlation coefficients between ordination scores and population abundances (log transformed) of the 15 most common sandfly species.

\begin{tabular}{|c|c|c|}
\hline Species & Ordination axis 1 & Ordination axis 2 \\
\hline L. flaviscutellata & $-0.782^{\mathrm{c}}$ & -0.322 \\
\hline L. lainsoni & -0.113 & $-0.825^{\mathrm{c}}$ \\
\hline L. davisi & $-0.835^{\mathrm{c}}$ & -0.175 \\
\hline L. whitmani & $-0.676^{\mathrm{c}}$ & 0.286 \\
\hline L. complexa & $-0.553^{\mathrm{b}}$ & -0.287 \\
\hline L. claustrei & -0.216 & $-0.565^{\mathrm{b}}$ \\
\hline L. hirsutus & $-0.660^{\mathrm{c}}$ & 0.091 \\
\hline L. llanosmartinsi & -0.352 & 0.187 \\
\hline L. ubiquitalis & 0.108 & $-0.682^{\mathrm{c}}$ \\
\hline L. migonei & $-0.416^{\mathrm{a}}$ & $0.421^{\mathrm{a}}$ \\
\hline L. shawi & -0.252 & $-0.578^{\mathrm{b}}$ \\
\hline L. nevezi & $-0.719^{\mathrm{c}}$ & 0.118 \\
\hline B. brumpti & $-0.678^{\mathrm{c}}$ & 0.204 \\
\hline L. antunesi & -0.184 & -0.136 \\
\hline L. octavioi & -0.235 & -0.246 \\
\hline
\end{tabular}

${ }^{\mathrm{a}} \mathrm{p}<0.05 ;{ }^{\mathrm{b}} \mathrm{p}<0.01 ;{ }^{\mathrm{c}} \mathrm{p}<0.001$

Elsewhere in southern Amazonia this species has been collected only in forest environments (references in Young \& Duncan, 1994), and the distance of the pasture traps from the edge of the forest (30 and $150 \mathrm{~m}$ ) is well within the flight range recorded for other sandfly species (Killick-Kendrick et al., 1984). L. lainsoni, like most other species in the subgenus
Psychodopygus, is strongly attracted to ground-dwelling mammals, including humans and horses (Ward \& Killick-Kendrick, 1974). In uninhabited areas of the Amazon, the temporary presence of humans significantly affects the abundance of anthropophilic species of Lutzomya (Barrett et al., 1996), and therefore, by analogy, the aggregation of cattle may well have 
selectively attracted $L$. lainsoni from the forest into the pasture.

Contrasting to the situation observed in pastures, secondary forests contained a large subset of the species found in nearby primary forest. This suggests that forest regeneration in previously cultivated and abandoned lands results in a relatively rapid recovery of the sandfly fauna, although it must be stressed that our sampling sites were in relatively close proximity to primary forest, and therefore it is not clear if the same pattern will hold for more distant areas. Age since land abandonment seems to be of some importance in determining rates of recovery, since the youngest secondary forest studied here ( 3 yr. old) contained the lowest number of species.

However, we found no difference in species richness in the two other secondary forests, despite a difference in age of $10 \mathrm{yr}$ between the two, suggesting that recovery of the sandfly fauna is not simply a linear function of forest age.

About two-thirds of all species recorded in our study sites were found in the secondary forests. No species were exclusively found in secondary forests, but rather the species present represented a subset of those found in primary forests (Appendix 1). Also, none of the species attained higher densities in secondary than in primary forests, suggesting that no species can be classified as "open area" or "disturbance adapted" species. Species responses to forest fragmentation tend to be highly individualistic, depending on intrinsic habitat requirements. Species with large area requirements and species that avoid the edge and the matrix tend to decline in abundance, whereas edge- and disturbance-favoring species are not affected or even become more abundant in fragmented forests. (Offerman et al., 1995; Stouffer \& Bierregaard Jr., 1995; Gascon et al., 1999). Our data indicate that most sandfly species recorded in this study have similar habitat requirements and therefore that their responses to forest fragmentation and forest disturbance are likely to be convergent.

We have found no evidence for an effect of distance to forest edge on sandflies, at least not within the distance classes analyzed here. Previous studies show that edge effects appear when there is an influx of species and/or individuals from the surrounding matrix (Laurance et al., 1997b). However, none of the species we recorded could be regarded as a matrix species, so invasion of matrix associated species, as for instance seen for frogs (Tocher et al., 1997) and butterflies (Lovejoy et al., 1986; Brown \& Hutchings,
1997), was not the case here. Edge effects can also result from in situ environmental and/or biotic differences between the edge and the forest interior. Many studies have shown that vegetation structure and forest microclimate is altered near forest edges (Kapos et al., 1997; Gascon et al., 2000). However, these changes were possibly not of sufficient magnitude to affect sandfly populations.

More individuals and species of sandflies were found in primary forest areas adjacent to pastures than those adjacent to secondary forests. The limited number of remnants of primary forest studied precludes any generalizations about these findings. However, in a study near Manaus (Malcolm, 1997b), similar findings were obtained and a greater abundance of Diptera in fragments surrounded by pastures were detected than those surrounded by secondary forests. It is interesting to notice that here differences in the abundance and diversity of sandflies were detected even within the same fragment, between edges facing pastures and those facing secondary forests. More detailed studies are needed to determine if there are differences in forest structure and abundance of vertebrate hosts between the two types of forest edges. Some sandfly species, including especially L. flaviscutellata, are favored by the opening of treefall gaps, since gaps have better conditions for growing larvae and also sustain larger populations of vertebrate hosts, particularly rodents (Ready et al., 1983). Rates of tree mortality, and therefore of gap creation, are particularly high during the first five years after the opening of a new forest edge, but decline afterwards (Kapos et al., 1997; Laurance et al., 1997a). Therefore, it is likely that newly created forest edges will be more favorable than older edges to some sandflies. If so, it is possible that the observed differences in abundance and richness of sandflies between edges facing pastures and those facing secondary forests are in fact due to age since edge creation, since in all three sites studied, crops and plantations (from which secondary forests originated, subsequent to land abandonment) were established earlier than pastures.

Regardless of the exact mechanisms determining the observed differences between the two types of forest edges, it is interesting to notice that L. flaviscutellata, a vector of leishmaniasis to humans in the Amazon (Lainson \& Shaw, 1968), was significantly more abundant in the forest edges adjacent to pastures. The same pattern was not detected with regard to the two other sandfly species 
known, or suspected to be vectors, including $L$. umbratalis and L. whitmani (Lainson \& Shaw, 1968).

Acknowledgments - This work was made possible with funds from the Projeto de Pesquisa Dirigida (PPD - FINEP/MCT/ PPG7) "Phlebotominae, Triatominae e Trypanosomatinae associadas: diagnósticos e monitoramento da diversidade biológica na Amazônia e interacões com as populações humanas", and the Biological Dynamics of Forest Fragments Project (BDFFP) (INPA/Smithsonian). Dr. Rui Alves de Freitas, from INPA-CPCS, kindly helped with specimen identifications. Roger Hutchings and an anonymous reviewer read and commented on an earlier version of the manuscript. This is publication number 374 in the BDFFP Technical Series.

\section{REFERENCES}

BARRETT, T. V., FREITAS, R. A., ALBUQUERQUE, M. I. C. \& GUERRERO, J. H. C., 1996, Report on a collection of Lutzomya sandflies (Diptera: Psychodidae) from the Middle Solimões (Amazonas, Brazil). Mem. Inst. Oswaldo Cruz, 91: 27-35.

BROWN, K. S. Jr. \& HUTCHINGS, R. W., 1997, Disturbance, fragmentation, and the dynamics of diversity in Amazonian forest butterflies. In: W. F. Laurance \& R. O. Bierregaard Jr. (eds.), Tropical forest remnants: ecology, management, and conservationof fragmented communities. University of Chicago Press, Chicago, pp. 91-110.

CARVALHO, K. S. \& VASCONCELOS, H. L., 1999, Forest fragmentation in central Amazonia and its effects on litterdwelling ants. Biol. Cons., 91: 151-158.

DIDHAM, R. K., 1997, An overview of invertebrate responses to forest fragmentation. In: A. D. Watt, N. E. Stork \& M. D. Hunter (eds.), Forest and insects. Chapman and Hall, London, pp. 303-320.

DIDHAM, R. K. \& LAWTON, J. H., 1999, Edge structure determines the magnitude of changes in microclimate and vegetation structure in tropical forest fragments. Biotropica, 31: 17-30.

DISNEY, R. H. L., 1966, A trap for phlebotomine sandflies attracted to rats. Bull. Ent. Res., 56: 445-451.

GASCON, C., LOVEJOY, T. E., BIERREGAARD Jr., R. O., MALCOLM, J. R., STOUFFER, P. C., VASCONCELOS, H. L., LAURANCE, W. F., ZIMMERMAN, B., TOCHER, M. \& BORGES, S., 1999, Matrix habitat and species richness in tropical forest remnants. Biological Conservation, 91: 223-230.

GASCON, C., WILliAMSON, B. G. \& DA FONSECA, G. A. B., 2000, Receding forest edges and vanishing reserves. Science, 288: 1356-1358.

KAPOS, V., WANDELLI, E., CAMARGO, J. L. C. \& GANADE, G., 1997, Edge-related changes in environment and plant responses due to forest fragmentation in central Amazonia. In: W. F. Laurence \& R. O. Bierregaard Jr. (eds.), Tropical forest remnants: ecology, management, and conservation of fragmented communities. University of Chicago Press, Chicago, pp. 33-44.
KILLICK-KENDRICK, R., RIOUX, J. A., GUY, M. W., WILKES, T. J., GUY, F. M., DAVIDSON, I., KNECHTLI, R., WARD, R. D., GULIVARD, E., PERIERES, J. \& DUBOIS, H., 1984, Ecology of leishmaniasis in the south of France. 20. Dispersal of Phlebotomus ariasis Tonnoir, 1921 as a factor in the spread of visceral leishmaniasis in the Cévennes. Ann. Parasitol. Hum. Comp., 59: 555-572.

LAISON, R. \& SHAW, J. J., 1968, Leishmaniasis in Brazil: I. Observations of enzootic rodent leishmaniasis incrimination of Lutzomia flaviscutellata (Mangabeira) as the vector in the lower Amazon basin. Trans. R. Soc. Trop. Med. Hyg., 62: 385-395.

LAURANCE, W. F., 1991, Ecological correlates of extinction proneness in Australian tropical rainforest mammals. Conservation Biology, 5: 79-89.

LAURANCE, W. F., LAURANCE, S. G., FERREIRA, L. V., RANKIN-DE-MERONA, J. M., GASCON, C. \& LOVEJOY, T. E., 1997a, Biomass collapse in Amazonian forest fragments. Science, 278: 1117-1118.

LAURANCE, W. F., BIERREGAARD Jr., R. O., GASCON, C., DIDHAM, R. K., SMITH, A. P., LYNAM, A. J., VIANA, V. M., LOVEJOY, T. E., SIEVEING, K. E., SITES, J. W., ANDERSEN, M., TOCHER, M. D., KRAMER, E. A., RESTREPO, C. \& MORITZ, C., 1997b, Tropical forest fragmentation: synthesis of a diverse and dynamic discipline. In: W. F. Laurance \& R. O. Bierregaard Jr. (eds.), Tropical forest remnants: ecology, management, and conservation of fragmented communities. University of Chicago Press, Chicago, pp. 502-514.

LOVEJOY, T. E., BIERREGAARD, R. O. J., RYLANDS, A. B., MALCOLM, J. R., QUINTELA, C. E., HARPER, L. H., BROWN, K. S. J., POWELL, A. H., POWELL, G. V. N., SCHUBART, H. O. R. \& HAYS, M. B., 1986, Edge and other effects of isolation on Amazon forest fragments. In: M. Soule (ed.), Conservation biology: the science of scarcity and diversity. Sinauer Associates, Inc., Sunderland, Massachussets, pp. 257-285.

MALCOLM, J. R., 1994, Edge effects in central Amazonian forest fragments. Ecology, 75: 2438-2445.

MALCOLM, J. R., 1997a, Biomass and diversity of small mammals in forest fragments. In: W. F. Laurance \& R. O. Bierregaard Jr. (eds.), Tropical forest remnants: ecology, management, and conservation of fragmented communities. University of Chicago Press, Chicago, III. USA, pp. 207-221.

MALCOLM, J. R., 1997b, Insect biomass in Amazonian forest fragments. In: N. E. Stork, J. Adis \& R. K. Didham (eds.), Canopy arthropods. Chapman and Hall, London, pp. 510-533.

MESQUITA, R. C. G., DELAMONICA, P. \& LAURANCE, W. F., 1999, Effect of surrounding vegetation on edge-related tree mortality in Amazonian forest fragments. Biological Conservation, 91: 129-134.

MURCIA, C., 1995, Edge effects in fragmented forests: implications for conservation. Trends in Ecology and Evolution, 10: 58-62.

OFFERMAN, H., DALE, V. H., PEARSON, S. M., BIERREGAARD Jr., R. O. \& O’NEILL, R. V., 1995, Effects of forest fragmentation on neotropical fauna: current research and data availabiltiy. Environmental Reviews, 3: 191-211. 
READY, P. D., LAINSON, R. \& SHAW, J. J., 1983, Leishmaniasis in Brazil. XX. Prevalence of enzootic rodent leishmaniasis (Leishmania mexicana amazonensis), and apparent absence of "pian bois" (Le. braziliensis guyanensis), in plantations of introduced tree species and in other nonclimax forests in eastern Amazonia. Trans. R. Soc. Trop. Med. Hyg., 77: 775-785.

SAUNDERS, D. A., HOBBS, R. J. \& MARGULES, C. R., 1991, Biological consequences of ecosystem fragmentation: a review. Conservation Biology, 5: 18-29.

STOUFFER, P. \& BIERREGAARD Jr., R. O., 1995, Effects of forest fragmentation on understory hummingbirds in Amazonia, Brazil. Conservation Biology, 9: 1085-1094.

SUDIA, W. D. \& CHAMBERLAIN, R. W., 1962, Battery operated light trap, an improved model. Mosquito News, 22: $126-129$.
TOCHER, M., GASCON, C. \& ZIMMERMAN, B., 1997. Fragmentation effects on a central Amazonian frog community: a ten-year study. In: W. F. Laurence \& R. O. Bierregaard Jr. (eds.), Tropical forest remnants: ecology, management, and conservation of fragmented communities. University of Chicago Press, Chicago, USA, pp. 124-137.

WARD, R. D. \& KILLICK-KENDRICK, R., 1974, Field and laboratory observations on Psychodopygus lainsoni Fraiha $\&$ Ward and other sandflies (Diptera: Phlebotomidae) from the Transamazônica highway, Pará state, Brazil. Bull. Ent. Res, 64: 213-221.

YOUNG, D. G. \& DUNCAN, M. A., 1994, Guide to the identification and geographic distribution of Lutzomya sand flies in Mexico, the West Indies, Central and South America (Diptera: Psychodidae). Memoirs of the American Entomological Institute no 54, Associated Publishers, Gainesville.

\section{APPENDIX 1}

List of the sandfly species collected in remnants of primary forest and adjacent matrix habitats in Alta Floresta, Brazil. Numbers refer to the total of individuals collected in CDC and Disney traps.

\begin{tabular}{|l|c|c|c|c|}
\hline \multicolumn{1}{|c|}{ Species } & $\begin{array}{c}\text { Primary forest } \\
\text { (adjacent to pasture) }\end{array}$ & $\begin{array}{c}\text { Primary forest } \\
\text { (adjacent to 2 }\end{array}$ forest) & $\begin{array}{c}\text { Secondary } \\
\text { forest }\end{array}$ & Pasture \\
\hline Lutzomyia acanthopharynx & 16 & 2 & 0 & 0 \\
\hline L. amazonensis & 3 & 1 & 0 & 0 \\
\hline L. antunesi & 12 & 17 & 3 & 11 \\
\hline L. aragaoi & 5 & 3 & 2 & 0 \\
\hline L. ayrozai & 8 & 2 & 1 & 0 \\
\hline L. baculus & 8 & 6 & 1 & 0 \\
\hline L. barrettoi & 1 & 0 & 0 & 1 \\
\hline L. carrerai & 24 & 14 & 0 & 1 \\
\hline L. choti & 1 & 7 & 2 & 0 \\
\hline L. claustrei & 50 & 24 & 1 & 0 \\
\hline L. complexa & 59 & 21 & 19 & 2 \\
\hline L. dasypodogeton & 7 & 13 & 5 & 0 \\
\hline L. davisi & 218 & 136 & 40 & 4 \\
\hline L. dendrophyla & 5 & 3 & 1 & 0 \\
\hline L. fischeri & 0 & 1 & 0 & 0 \\
\hline L. flaviscutellata & 328 & 102 & 11 & 0 \\
\hline L. furcata & 10 & 10 & 2 & 0 \\
\hline L. geniculata & 3 & 1 & 0 & 0 \\
\hline L. gomezi & 9 & 6 & 1 & 0 \\
\hline L. hermanlenti & 20 & 2 & 4 & 2 \\
\hline L. hirsutas & 13 & & 0 & 1 \\
\hline L. inflata & & 25 & \\
\hline
\end{tabular}




\section{APPENDIX 1 (Continued)}

\begin{tabular}{|c|c|c|c|c|}
\hline Species & $\begin{array}{c}\text { Primary forest } \\
\text { (adjacent to pasture) }\end{array}$ & $\begin{array}{c}\text { Primary forest } \\
\text { (adjacent to } 2^{\text {nd }} \text { forest) }\end{array}$ & $\begin{array}{l}\text { Secondary } \\
\text { forest }\end{array}$ & Pasture \\
\hline L. infraspinosa & 5 & 3 & 0 & 0 \\
\hline L. lainsoni & 349 & 54 & 51 & 1162 \\
\hline L. llanosmartinsi & 22 & 20 & 18 & 2 \\
\hline L. lutziana & 7 & 2 & 2 & 0 \\
\hline L. micropyga & 1 & 6 & 0 & 0 \\
\hline L. migonei & 15 & 12 & 32 & 0 \\
\hline L. monstruosa & 6 & 3 & 2 & 0 \\
\hline L. nevesi & 39 & 7 & 0 & 0 \\
\hline L. octavioi & 11 & 30 & 2 & 0 \\
\hline L. olmeca nociva & 1 & 0 & 0 & 0 \\
\hline L. pacae & 1 & 1 & 0 & 0 \\
\hline L. pusilla & 1 & 13 & 1 & 0 \\
\hline L. readyi & 2 & 1 & 1 & 0 \\
\hline L. richardwardi & 4 & 15 & 9 & 1 \\
\hline \begin{tabular}{|l|} 
L. saulensis \\
\end{tabular} & 4 & 0 & 0 & 0 \\
\hline L. scaffi & 2 & 1 & 0 & 0 \\
\hline L. sericea & 2 & 0 & 0 & 0 \\
\hline L. serrana & 25 & 11 & 2 & 0 \\
\hline L. servulolimai & 10 & 7 & 1 & 0 \\
\hline L. shannoni & 2 & 1 & 0 & 0 \\
\hline L. shawi & 34 & 20 & 3 & 0 \\
\hline L. sordellii & 15 & 1 & 1 & 1 \\
\hline L. termitophila & 15 & 1 & 1 & 22 \\
\hline L. triacantha & 2 & 4 & 2 & 0 \\
\hline L. ubiquitalis & 22 & 20 & 19 & 1 \\
\hline L. umbratilis & 6 & 15 & 8 & 1 \\
\hline L. walkeri & 3 & 0 & 1 & 0 \\
\hline L. whitmani & 66 & 102 & 44 & 2 \\
\hline L. yuilli & 3 & 0 & 0 & 0 \\
\hline L. yucumensis & 22 & 6 & 7 & 0 \\
\hline L. (Pressatia) sp.* & 10 & 21 & 2 & 1 \\
\hline Brumptomyia brumpti & 30 & 14 & 0 & 0 \\
\hline B. pentacantha & 2 & 1 & 0 & 0 \\
\hline B. pintoi & 1 & 0 & 1 & 0 \\
\hline Brumptomyia sp. & 11 & 11 & 8 & 2 \\
\hline
\end{tabular}

* Females of L. choti and/or L. triacantha. 